\title{
PENERAPAN RANCANGAN SISTEM E-VOTING DALAM PEMILIHAN KETUA BEM (BADAN EKSLUSIF MAHASISWA) STUDI KASUS UNIVERSITAS BORNEO TARAKAN
}

\author{
Rahmat Ismanto ${ }^{1}$, Awang Pradana ${ }^{2}$ \\ ${ }^{1}$ Universitas Borneo Tarakan, Tarakan, Kalimantan Utara, 77111, Indonesia \\ ${ }^{2}$ Universitas Borneo Tarakan, Tarakan, Kalimantan Utara, 77111, Indonesia \\ e-mail: ${ }^{1}$ ismantorahmat@gmail.com, ${ }^{2}$ awang.pradana@borneo.ac.id
}

\begin{tabular}{ccc}
\hline Diterima & Direvisi & Disetujui \\
$30-09-2021$ & $07-10-2021$ & $19-10-2021$ \\
\hline
\end{tabular}

\begin{abstract}
At the beginning of the determination of the corona virus pandemic in 2020 in Indonesia, the Indonesian government gave directions to always live clean and healthy by washing hands, maintaining distance, and wearing masks. Several regions in Indonesia are also experiencing lockdown conditions, things that people usually do face to face are experiencing problems in terms of economy, development, education and others as a result of the state of the area being or in a state of lockdown, but it is not a problem when activities are carried out. switch to an online system. Especially in the field of education, the learning system has also switched to an online system, the University Borneo Tarakan has also implemented an online system for teaching and learning activities, research to making a decision in terms of selecting the chairman or head of the division within the division, this research tries to implement an e-voting system in regarding the election of the chairman of the BEM (Badan Eksekutif Mahasiswa) period 2021. This study aims that students who have voting rights or voting rights can channel their voting rights by determining the pair of candidates that are in accordance with what they want without having to come to the location, simply by using an internet connection and gadgets. With this e-voting system, it is hoped that activities in conducting the election of the chairman of the team can run well and can take advantage of the conditions during this pandemic.
\end{abstract}

Keywords: web voting; e-voting; online system; online; universitas borneo tarakan

\begin{abstract}
Abstrak: Awal penetapan pandemi virus corona pada tahun 2020 di indonesia, pemeritah indonesia memberikan arah untuk selalu hidup bersih dan sehat dengan cara mencuci tangan,menjaga jarak,serta mengenakan masker. Beberapa daerah di indonesia pun mengalami kondisi lockdown, hal yang biasa dilakukan masyarakat secara tatap muka tersebut mengalami masalah baik segi ekonomi, pembangunan, pendidikan dan lain-lain akibat dari keadaan daerah yang sedang atau dalam kondisi lockdown, namun tidak menjadi masalah ketika kegiatankegiatan tersebut beralih ke sistem online atau pun biasa di kenal dengan kata daring (dalam jaringan). Terkhusus dalam bidang pendidikan sistem pembelajaran pun beralih ke sistem daring, universitas borneo tarakan pun menerapkan sistem daring baik kegiatan belajar mengajar, penelitian sampai dengan melakukan sebuah keputusan dalam hal pemilihan ketua atau kepala bidang di dalam divisi, penelitian ini mencoba menerapkan sistem e-voting dalam hal pemilihan ketua BEM (Badan Eksklusif Mahasiswa) periode tahun 2021. Penelitian ini bertujuan agar mahasiswa yang mempunyai hak suara atau hak pilih dapat menyalurkan hak suaranya dengan menentukan pasangan calon kandidat yang sesuai dengan yang di inginkan tanpa harus datang lokasi, cukup dengan memanfaatkan koneksi internet dan gadget. Dengan adanya sistem $e$-voting ini di harapkan kegiatan dalam melakukan pemilihan ketua bem dapat berjalan dengan baik serta dapat memanfaatkan kondisi di masa pandemi ini.
\end{abstract}

Kata kunci: web voting; e-voting; sistem online; daring; universitas borneo tarakan 


\section{PENDAHULUAN}

Pada masa pandemi yang disebabkan oleh Covid-19 (corona virus disease) pemeritah indonesia menetapkan sebagai bencana nasional, ini di sampaikan langsung oleh bapak presiden joko widodo melalui keppres yang diterbitkan nomor 12 tahun 2020 tentang penetapan bencana nasional (Keppres No 12 Tahun 2O2O Tentang Penetapan Bencana Nonalam Penyebaran Corona Virus Disease 2019 Sebagai Bencana Nasional, 2020). Dengan adanya musibah bencana nasional dan menguraingi resiko penularan maka dari itu pemerintah indonesia melakukan beberapa kebijakan yaitu dengan melakukan psbb (pembatasan sosial berskala besar) dan mulai diberlakukan pada tanggal 1 april 2020. PSBB ini di atur dalam PP (peraturan pemerintah) Nomor 21 tahun 2020. Terdapat banyak dampak yang di timbulkan setelah di berlakukannya psbb ini, salah satunya di dalam ranah pendidikan. Kampus UBT (universitas borneo tarakan) menerapkan perkuliahan dan seluruh aktivitas kampus secara full daring (dalam jaringan) melalui surat edaran tentang pencegahan covid-19 bagi lingkup kampus (Universitas borneo tarakan, 2020). Kampus ubt mempunyai struktur organisasi khusus untuk mahasiswa yaitu BEM (Badan Eksekutif Mahasiswa), BEM UBT ini mempunyai tugas pokok dalam hal memberikan informasi mengenai perkuliahan, seminar, kegiatan bakti sosial dan kegiatan apa saja yang menyangkut masalah mahasiswa di universitas borneo tarakan sendiri. Pada tahun 2021 bulan januari kepengurusan anggota BEM periode tahun sebelumnya masa bakti telah selesai, dan pada bulan maret dilakukan pemilihan kembali calon kandidat yang baru. Pada tahun 2021 bulan februari rektor ubt menerbitkan surat edaran terkait peyelengaraan pembelajaran dan kegiatan yang ada di kampus dalam hal ini organisasi BEM yang ingin melakukan pemilihan terkendala dalam hal kegiatan pemilihan calon kandidat baru kepengurusan BEM, dengan melalui kordinasi, rapat serta keputusan oleh biro akademik kemahasiswaan dan kerjasama maka pemilihan calon kandidat BEM tersebut pemungutan suara di lakukan secara online. Tujuan terbentuknya BEM universitas borneo tarakan ini salah satunya adalah untuk mewadahi antusiasme kegiatan mahasiswa kepada universitas, sehingga dapat menaikan pengaruh kepuasan yang signifikan terhadap loyalitas mahasiswa di universitas borneo tarakan (Karunia, 2020).

Menurut (Loura \& Megawati, 2011) suatu saat akan muncul terobosan baru dalam lingkup pemilihan umum dengan metode yang dapat mengatasi keefisiensi dan efektif dalam melaksanakan pemilihan umum dilihat prospek dari segi biaya, tenaga dan waktu namun tetap memenuhi asas kaidah yang diterapkan. Sistem pemungutan suara merupakan kegiatan yang sangat riskan dalam hal perhelatan pengambilan keputusan banyak kepentingan yang mestinya di akomodir di dalamnya (Ridwan et al., 2016). Adapun Pada penelitian (Martono, 2017) melakukan pengembangan terhadap algoritma RSA tujuannya untuk meningkatkan kerahasiaan dan keamanan data pada database. Pemungutan suara yang biasa dilakukan secara offline/ secara langsung yang menggunakan kertas, ini dilakukan oleh organisasi BEM di universitas borneo tarakan, selama masa pandemi ini belum berakhir maka kegiatan yang dilakukan secara offline di alihkan pada sistem secara online, pemungutan suara tersebut dilakukan secara online menggunakan sistem $e$ voting. Sistem secara e-voting ini merupakan sebuah solusi teknologi yang sangat membantu dimasa pandemi seperti ini, melalui laman website yang di fasilitasi oleh UPT TIK kampus Universitas Borneo Tarakan.

Penelitian ini membuat suatu sistem e-voting berbasis website dengan bertujuan untuk memudahkan mahasiswa yang ikut berpatisipasi dalam menyukseskan pemilihan ketua BEM yang ada di univertias borneo tarakan periode 2021. Aturan didalam sistem e-voting ini akan diintegrasikan ke sistem polling dan mengacu pada peraturan ormawa (organisasi kemahasiswaan) yang telah di sepakati juga oleh BAKK (Biro Akademik, Kemahasiswaan dan Kerjasama), diantaranya peraturan ormawa tentang pedoman tata cara pelaksanaan pemungutan dan penghitungan suara pemilihan umum ketua dan wakil ketua BEM di universitas borneo tarakan. Penelitian ini mengutamakan proses keamanan, kenyaman pemilih, transparan dalam artian hasil voting langsung menampilkan persentase suara yang sudah terpilih calon kandidat, keakuratan hasil voting yang diperoleh, dan robustness atau seluruh pihak tidak dapat menghambat, mempengaruhi pemilih dan perhitungan akhir voting. Dengan adanya penelitian ini diharapkan di 
masa yang akan datang sistem e-voting dapat digunakan oleh seluruh lembaga universitas borneo tarakan dalam pemilihan kepala bidang ataupun pengambilan sebuah keputusan baik dalam pendidikan ataupun pengajaran, dimana utamanya agar dapat menghindari kerumunan karena situasi masih dalam masa pandemi Covid 19, mengurangi dampak penggunaan kertas yang berlebih dan menghemat biaya dalam melakukan pemungutan suara.

\section{METODE PENELITIAN}

\section{Rancangan Penelitian}

Pada rancangan penelitian ini bermula dari tahap kebutuhan akan adanya sistem informasi berupa penyelenggaraan pemilihan ketua dan wakil BEM universitas borneo tarakan masa jabatan 2021 dan sesuai dengan kesepakatan dari berbagai pihak maka pemungutan suara ini akan dilaksanakan secara online. Dikategorikam sangat baik ketika sistem e-voting ini mempunyai gambaran rancangan sistem yang baik (Nawindah \& Akhmad, 2014) dalam hal proses pemungutan suara yaitu cepat, perhitungan hasil akurat, resiko kesalahan sangat minim dan hemat biaya.

Sistem $e$-voting ini mempunyai alur mekanisme dapat dilihat pada gambar 1, yang merupakan flowchart dari sistem $e$-voting ini.

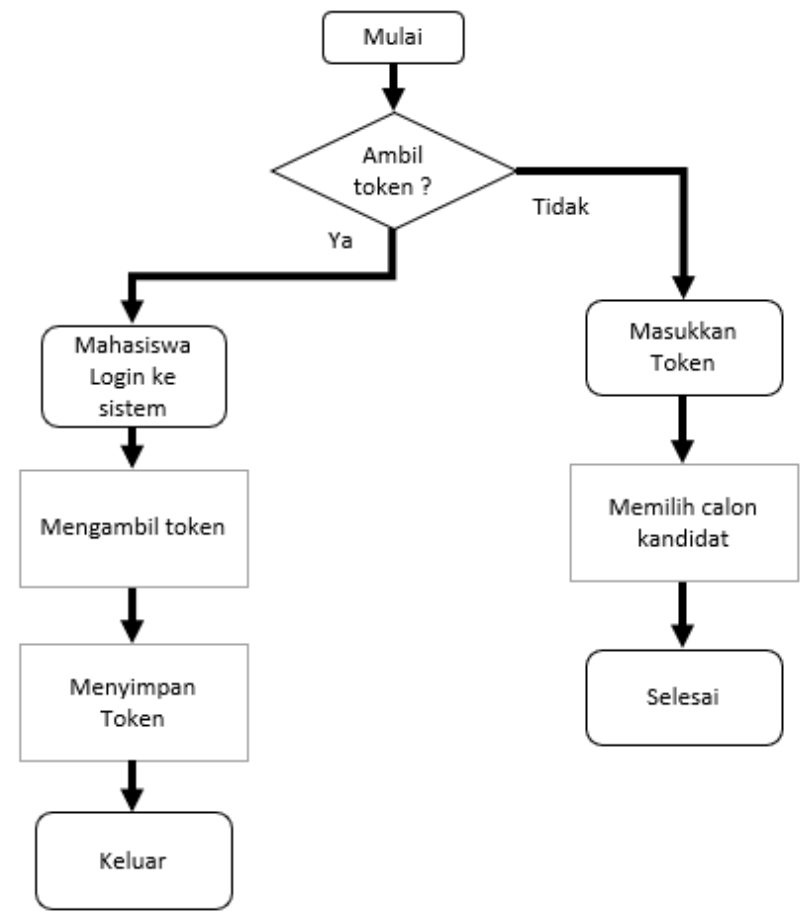

Gambar 1. Diagram alur sistem $e$-voting

Penjelasan mengenai flowchart tersebut akan dibahas pada bab III mengenai pembahasan alur kerja sistem.

\section{Subjek Penelitian}

Penentuan subjek penelitian sangat dianjurkan kemudian setelahnya menata langkah untuk memulai step by step dari penelitian tersebut, variabel yang ada di dalam subjek penelitian inilah yang menentukan batasan penelitian (Arikunto, 2011). BEM (Badan Eksekutif Mahasiswa) organisasi resmi yang ada di setiap perguruan tinggi. Tugas pokok dari BEM ini sendiri yaitu 
mengkoordinasikan organisasi kegiatan mahasiswa, mewakili suara mahasiswa atas usul dan saran yang di tujukan kepada petinggi atau pimpinan perguruan tinggi dalam hal peran,fungsi dan pendidikan.

\section{Instrumen}

Instrumen penelitian ini mengacu pada metode observasi dimana jenis dari metode ini sangat populer digunakan dalam penelitian terutamanya adalah dibidang ilmu perilaku dan ilmu sosial (Akinade \& Owolabi, 2009). Fleksibel dan mudah dijalankan ketika melakukan analisis data serta pengumpulan data.

\section{Prosedur Pengumpulan Data}

Data apa saja yang akan digunakan di dalam sistem e-voting ini merupakan data awal dan akhir dari penelitian serta program yang di jalankan. Adapun data yang dibutuhkan yaitu :

a. Data mahasiswa aktif

b. Data calon kandidat BEM

c. Data super admin (BAKK)

d. Data admin (Badan Pengawas Mahasiswa, UPT TIK)

\section{Analisis Data} fungsi

Pada tahap analisis data dapat dirumuskan menjadi 2 kebutuhan baik secara fungsi dan non

a. Kebutuhan fungsi

- Syarat pemilih

Di dalam sistem e-voting ini syarat wajib sebagai pemilih calon kandidat/ yang akan menyalurkan hak suaranya hanya mahasiswa yang aktif dimana mahasiswa tersebut memiliki NPM dan PASSWORD yang sama ketika akan login ke siakad.

- Pengambilan token

Mahasiswa dapat mengambil token dan mencatat kode token yang sudah diberikan oleh sistem, untuk memperoleh hak suara dan token tersebut hanya dapat diambil satu kali. Sebagai catatan kode token tersebut jangan sampai lupa ataupun hilang, apabila kode tersebut salah atau mahasiswa tersebut lupa maka hak suaranya akan hangus.

- Pemungutan suara

Hanya mahasiswa yang memiliki kode token saja yang dapat memberikan hak suara untuk melakukan pemilihan calon kandidat. Terlepas mahasiswa tersebut memilih atau tidak memilih dan hak suara tersebut akan hangus jika mahasiswa tersebut lupa atau tidak mencatat kode token yang sebelumnya sudah diberikan.

- Hasil perhitungan suara

Hasil perhitungan tersebut dapat dilihat secara langsung di laman resmi universitas borneo tarakan, dimana hasil tersebut akan muncul berupa diagram persentase jumlah mahasiswa yang memilih calon kandidatnya.

- Laporan keseluruhan

Laporan dari seluruh kegiatan akan dicatat ke dalam history laman pemilihan tersebut, yang di inputkan oleh admin dan super admin, laporan jumlah mahasiswa yang aktif, laporan jumlah mahasiswa yang mengambil token, laporan mahasiswa yang memilih serta laporan hasil perhitungan suara keseluruhan.

b. Kebutuhan non fungsi

- Kelayakan sistem

Rancangan sistem e-voting ini di desain menggunakan antarmuka yang sederhana agar mahasiswa yang memilih tidak kesulitan dalam hal akses alur pemilihan, dengan tata letak tombol box fitur dilengkapi dengan keterangan dan foto dari calon kandidat, serta 
mahasiswa tidak lagi dipusingkan dengan alur registrasi, cukup menggunakan NPM dan password yang sama dengan siakad untuk login mengambil kode token.

- Keamanan sistem

Algoritma asimetrik digunakan pada penelitian ini menurut (Ungkawa et al., 2021) algoritma ini melakukan enkripsi dan deskripsi pada kunci publik yang berbeda. Untuk mengantisipasi kecurangan dalam hal pemungutan suara, penelitian ini menerapkan bahwa pemilih hanya boleh memilih/menyalurkan hak suaranya apabila sudah mengambil jatah kode token yang di berikan oleh sistem dan user hanya dapat mengambil token sekali.

- Kinerja jaringan

Stabil baik dari sisi client dan server, demi keamanan dari kinerja jaringan ketika melakukan pemungutan suara UPT TIK univertas borneo tarakan mengalihkan bandwith khusus untuk sistem $e$-voting BEM ini selama satu hari ketika hari pemilihan berlangsung.

- Kinerja sistem

Demi mendukung kinerja sistem yang baik, dari sisi server UPT TIK telah memfasilitasi dan menyiapkan server untuk sistem e-voting ini dan dari sisi client perangkat keras dan jaringan yang digunakan juga harus yang memadai.

Tabel 1. Tabel database

\begin{tabular}{llll}
\hline No & & \multicolumn{2}{c}{ Database Pemlihan BEM } \\
\cline { 2 - 4 } & Nama tabel & Columns & Deskripsi \\
\hline 1 & Kandidats & 9 & Item berisi 3 calon kandidat \\
2 & Migration & 3 & Item berisi data migrasi siakad \\
3 & Password_rset & 3 & Token reset \\
4 & Pemilihs & 11 & User pemilih \\
5 & Pemilus & 8 & Data pemilihan \\
6 & Personal akses & 9 & Data token \\
& token & & \\
7 & Users & 16 & Data admin dan BPM
\end{tabular}

Tabel 1, menunjukan jumlah tabel serta deskripsi singkat, terdiri dari tabel kandidats, tabel migration, password reset, pemilihs, pemilus, personal akses, token, dan users masing-masing tabel memiliki primary key dan ada yang tidak. Dari ke 7 tabel tersebut memiliki masing masing columns sebagaimana columns dari masing-masing tabel memiliki fungsi masing-masing.

\section{HASIL}

Pada bab kali ini akan menjelaskan bagaimana tampilan antarmuka dan implementasi jalannya sistem e-voting ini sendiri, berikut poinnya:

\section{Antarmuka Sistem}

Tampilan antar muka dibuat sedemikian rupa agar mahasiswa mudah mengakses dan menjankan bagaimana prosedur dalam melakukan pemilihan secara sistem e-voting. Bisa di lihat pada Gambar 2. 


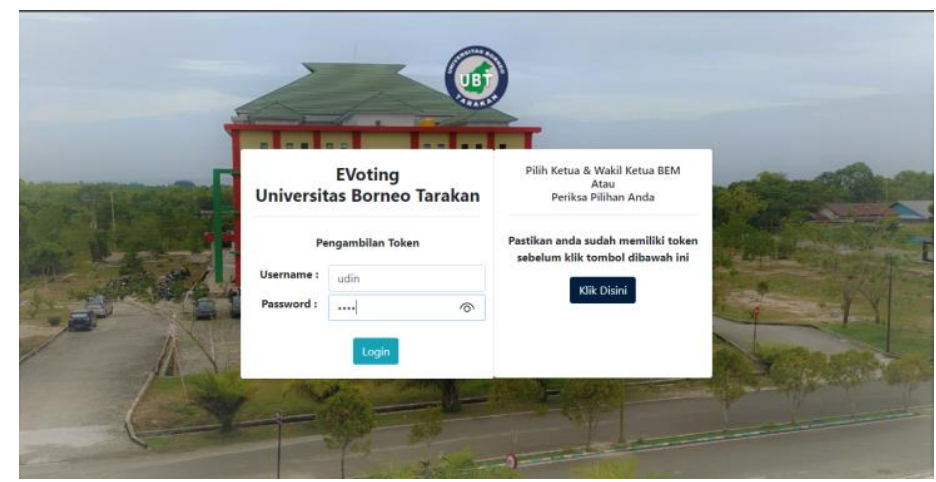

Gambar 2. Tampilan Antarmuka Sistem

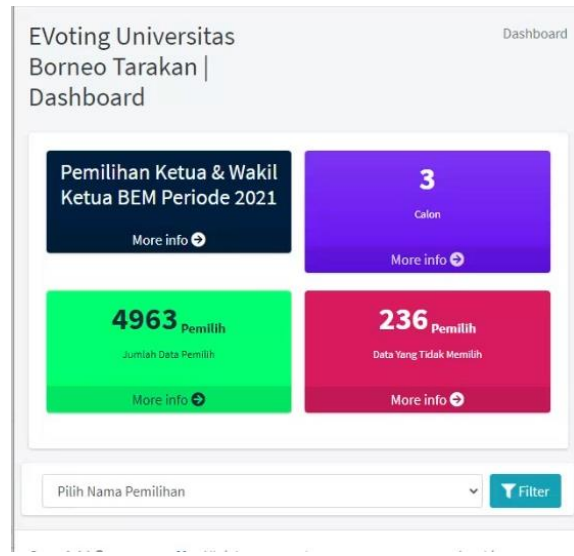

Gambar 3. Live voting jumlah data yang terekam di laman www.evoting.ubt.ac.id

Seluruh mahasiswa dapat melihat secara langsung hasil suara yang masuk baik data yang sudah memilih dan yang belum memilih, dapat dilihat pada Gambar 3. Serta chart e-voting hasil perolehan suara dapat dilihat pada grafik di Gambar 4. Pada akhir sesi atau di tutupnya proses pemungutan suara.

Real Count Pemilihan Ketua \& Wakil Ketua BEM Periode 2021 - 2025

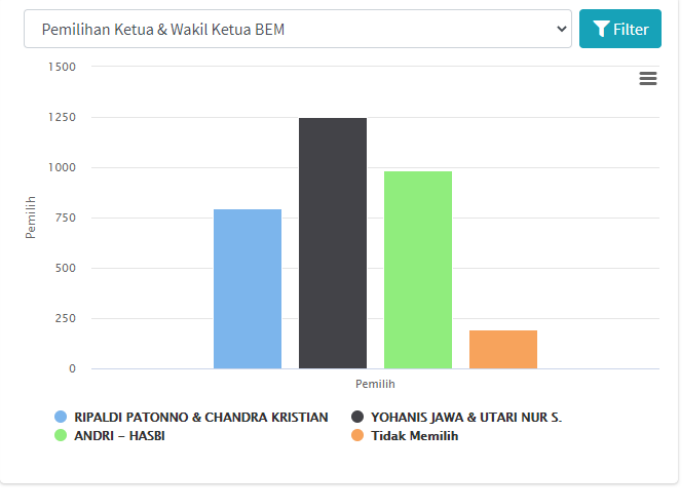

Gambar 4. Grafik hasil perhitungan suara 


\section{Implementasi Basis Data}

Melakukan implementasi basis data sebagai wadah penyimpanan master data dalam sistem $e$ voting ini harus memiliki alur berdasarkan data yang dibutuhkan. Berikut tampilan database yang diperlukan oleh sistem $e$-voting pada penelitian ini. Gambar 5 dan pada gambar 6 adalah database akun mahasiswa serta token.

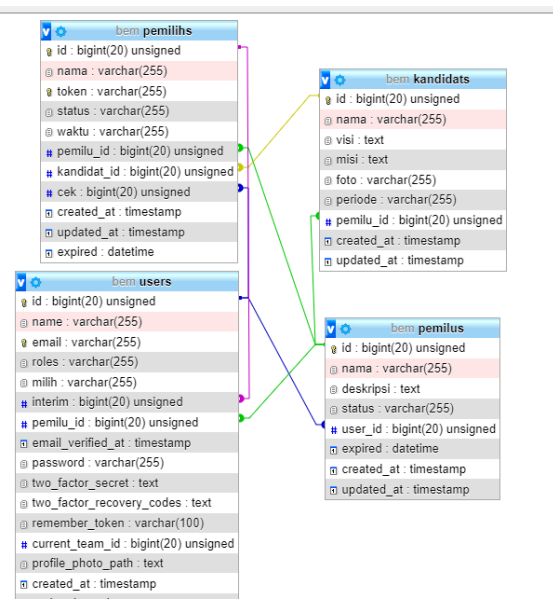

Gambar 5. Database alur pemilihan

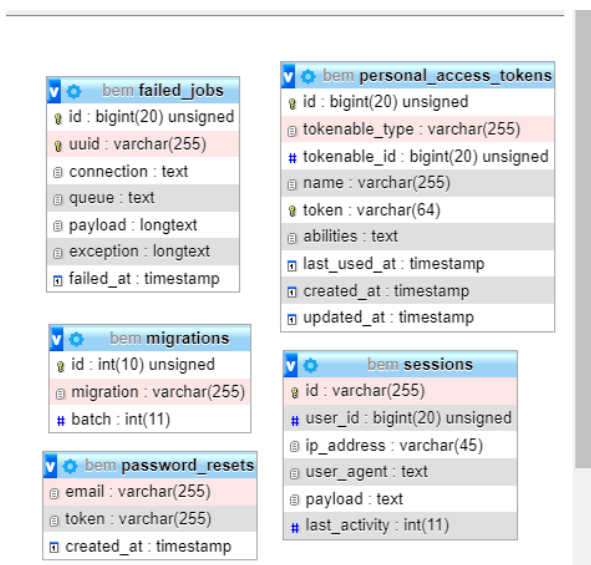

Gambar 6. Database akun mahasiswa dan token

\section{PEMBAHASAN}

\section{Alur Kerja Sistem}

Pada bagian bab pembahasan ini akan menjelaskan alur kerja sistem penelitian, dapat dilihat dari alur flowchart pada gambar 1. Berikut pembahasan mengenai sistem tersebut.

a. Mahasiswa yang ingin memilih calon kandidat merupakan mahasiswa aktif UBT, syaratnya yaitu memiliki NPM dan Password yang ada di siakad, data ini sudah di sinkronasi kan dan disepakati oleh pihak BAKK dan UPT TIK yang ada di UBT.

b. Mahasiswa sebelum melakukan pemilihan maka di wajibkan untuk mengambil TOKEN terlebih dahulu, fungsi token disini sebagai tiket untuk dapat memilih calon kandidat yang di ingikan, token ini bersifat rahasia dan token ini hanya dapat di gunakan satu kali saja per mahasiswa.

c. Setelah mahasiswa login menggunakan NPM dan Password, mahasiswa dapat mengambil kode token yang diberikan oleh system secara default, perlu di jadikan catatan bahwa kode token ini 
akan kadaluwarsa ketika mahasiswa tersebut sudah melakukan pemilihan dengan token yang sudah diberikan.

d. Setelah mendapatkan kode token, mahasiswa perlu mencatat atau mensalin kode token tersebut atau bisa dengan cara men-capture kode token tersebut. Dapat dilihat pada gambar 7.

e. Setelah menyimpan kode token tersebut, mahasiswa dapat keluar/ log out terlebih dahulu dari portal.

f. Ketika mahasiswa sudah mendapatkan token, maka mahasiswa tersebut dapat memilih dengan cara masukkan kode token di tempat yang sudah disediakan.

g. Masuk kedalam proses pemilihan calon kandidat, dapat di lihat pada gambar 8. sistem akan memberikan waktu 10 menit untuk mahasiswa melihat visi misi dari calon kandidat.

h. Setelah memilih calon kandidat maka otomatis sistem akan keluar dan memberikan notice bahwa mahasiswa dengan kode token tersebut telah memilih. Dapat dilihat pada gambar 9.

i. selesai

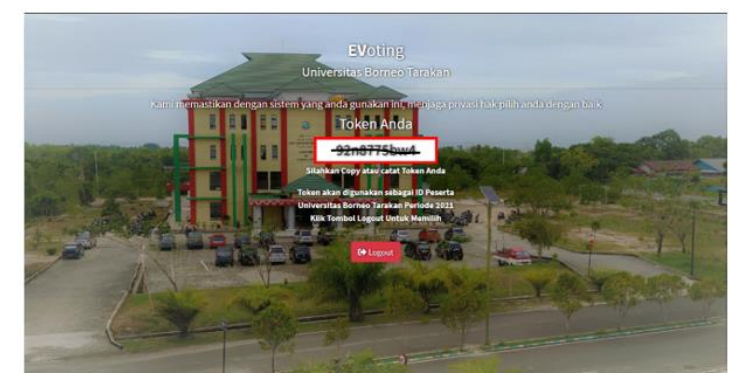

Gambar 7. Menampilkan token yang diperoleh

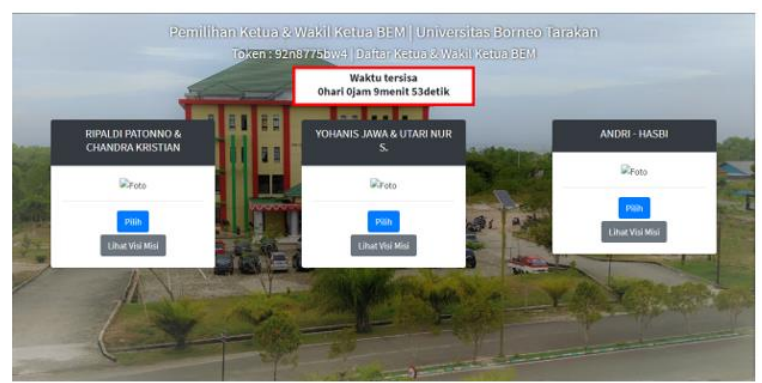

Gambar 8. Tampilan calon kandidat

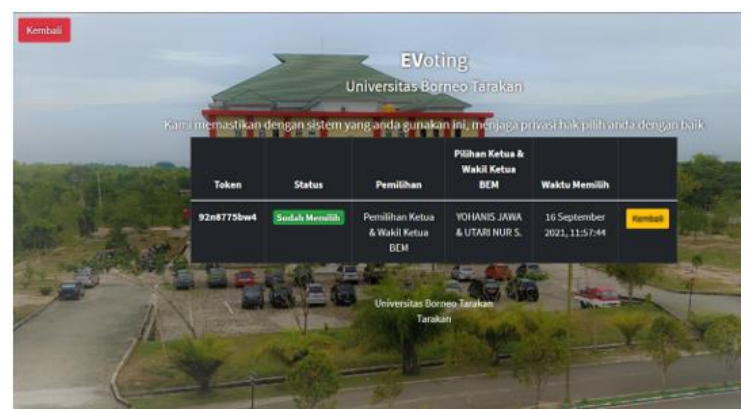

Gambar 9. Notice setelah memilih kandidat 


\section{Laporan hasil pemilihan}

Hasil dari e-voting ini akan dibuat juga dalam bentuk laporan hasil pemilihan ketua \& wakil ketua BEM, bentuk dari laporan sementara bisa dilihat pada gambar 10. Proses selanjutnya laporan tersebut akan di sepakati oleh ketua BPM, KPUM dan dari BAKK.

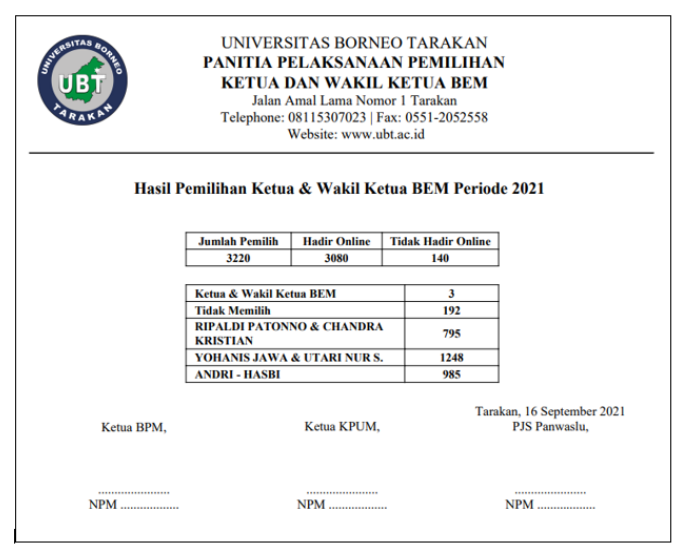

Gambar 10. Generate laporan sementara hasil pemilihan

\section{KESIMPULAN}

Rancangan sistem ini berjalan dengan baik, tanpa ada kendala dibuktikan dengan hasil perolehan suara yang sesuai dengan jumlah mahasiswa yang terdaftar dan mengikuti pemilihan BEM di Universitas Borneo Tarakan. Saran terkait penelitian selanjutnya dapat menambahkan pengembangan beberapa fitur keamanan terkait dalam hal pemilihan dengan menambahkan captcha code unik untuk login serta mengambil token.

\section{REFERENSI}

Akinade, E. A., \& Owolabi, T. (2009). Research methods: A pragmatic approach for social sciences, behavioural sciences and education. Lagos: Connel Publications.

Arikunto, S. (2011). Prosedur Penelitian: Suata Pendekatan Praktek. Rineka Cipta. https://books.google.co.id/books?id=aO5BAQAACAAJ

Karunia, E. (2020). Pengaruh Kualitas Layanan Pendidikan Terhadap Kepuasan, Loyalitas Mahasiswa Fakultas Ekonomi Universitas Borneo. Ecodemica, 4(1), 1-30. https://doi.org/10.31311/jeco.v4i1.7620

Keppres No 12 Tahun $2 \mathrm{O} 2 \mathrm{O}$ Tentang Penetapan Bencana Nonalam Penyebaran Corona Virus Disease 2019 Sebagai Bencana Nasional, Fundamental of Nursing 1 (2020).

Loura, H., \& Megawati, S. V. (2011). E-Voting: Kebutuhan vs . Kesiapan ( Menyongsong ) EDemokrasi. Jurnal Konstitusi, 8(4), 579-604.

Martono. (2017). Model Modifikasi Kriptografi Algoritma Rsa Untuk Keamanan Data Pada Database E-Voting. Jurnal Ilmiah Media Sisfo, 11(2), 896-910. http://ejournal.stikomdb.ac.id/index.php/mediasisfo/article/view/245

Nawindah, \& Akhmad, S. (2014). ANALISA PERANCANGAN DAN IMPLEMENTASI SISTEM INFORMASI E-VOTING UNTUK PEMILIHAN KETUA BEM PADA HIMPUNAN MAHASISWA JURUSAN TEKNIK GRAFIKA DAN PENERBITAN. SEMINAR NASIONAL MULTIDISIPLIN ILMU (SENMI) 2011201 UNIVERSITAS BUDI LUHUR, May, 151-156. https://doi.org/ISSN: 2087-0930

Ridwan, M., Arifin, Z., \& Yulianto, Y. (2016). Rancang Bangun E-Voting Dengan Menggunakan 
Keamanan Algoritma Rivest Shamir Adleman (RSA) Berbasis Web (Studi Kasus : Pemilihan Ketua Bem Fmipa). Informatika Mulawarman: Jurnal Ilmiah Ilmu Komputer, 11(2), 22. https://doi.org/10.30872/jim.v11i2.210

Ungkawa, U., Rosmala, D., \& Fauzi, H. (2021). Penerapan Advance Encryption Standart dalam Pengamanan Elektronik Voting. Journal of Information Technology, 3(1), 17-23. https://doi.org/10.47292/joint.v3i1.51

Universitas borneo tarakan. (2020). Surat Edaran Pencenggahan Covid-19 Bagi Lingkungan Universitas Borneo Tarakan. https://www.ubt.ac.id/wp-content/uploads/SURAT-EDARANTERKAIT-CORONA.pdf 